\title{
The challenge of the oceanic feeling: Romain Rolland's mystical critique of psychoanalysis and his call for a 'new science of the mind'
}

\author{
Ayon Maharaj \\ Ramakrishna Mission Vivekananda University, West Bengal, India
}

\begin{abstract}
In a letter written in 1927, the French writer Romain Rolland asked Sigmund Freud to analyse the 'oceanic feeling,' a religious feeling of oneness with the entire universe. I will argue that Rolland's intentions in introducing the oceanic feeling to Freud were much more complex, multifaceted, and critical than most scholars have acknowledged. To this end, I will examine Rolland's views on mysticism and psychoanalysis in his book-length biographies of the Indian saints Sri Ramakrishna and Swami Vivekananda, which he wrote just after he mentioned the oceanic feeling to Freud in 1927. I will argue that Rolland's primary intentions in appealing to the oceanic feeling in his 1927 letter to Freud - less evident in his letters to Freud than in his biographies of Sri Ramakrishna and Vivekananda - were to challenge the fundamental assumptions of psychoanalysis from a mystical perspective and to confront Freud with a mystical 'science of the mind' that he felt was more rigorous and comprehensive than Freud's psychoanalytic science.
\end{abstract}

\section{KEYWORDS}

Romain Rolland; Sigmund

Freud; psychoanalysis;

oceanic feeling; Swami

Vivekananda

The fascinating letters exchanged between Sigmund Freud and Romain Rolland from 1923 to 1936 have been a fertile source of discussion and debate among scholars and psychoanalysts. In 1927, Freud sent Rolland a copy of his new book, Die Zukunft einer Illusion, a polemical critique of religion from a psychoanalytic standpoint. In a momentous letter dated 5 December 1927, Rolland thanks Freud for sending his 'lucid and spirited little book' and goes on to remark:

Your analysis of religions is a just one. But I would have liked to see you doing an analysis of spontaneous religious sentiment or, more exactly, of religious feeling, which is wholly different from religions in the strict sense of the word, and much more durable.

What I mean is: totally independent of all dogma, all credo, all Church organization, all Sacred Books, all hope in a personal survival, etc., the simple and direct fact of the feeling of the 'eternal' (which can very well not be eternal, but simply without perceptible limits, and like oceanic, as it were). ${ }^{1}$ emphasis in the original

In the same letter, Rolland goes on to claim that the 'true subterranean source of religious energy' is none other than this "oceanic" sentiment." According to Rolland, while this oceanic feeling is 'of a subjective character,' it is nonetheless 'common to thousands (millions) of men actually existing.'3 He confesses that he himself has enjoyed this oceanic feeling as a 'constant state' and has 'always found in it a source of vital renewal. ${ }^{4}$

CONTACT Ayon Maharaj ayonmaharaj.rkm@gmail.com

'William Parsons, The Enigma of the Oceanic Feeling (New York: Oxford University Press, 1999), 173.

${ }^{2}$ lbid.

${ }^{3}$ lbid.

${ }^{4}$ Ibid.

๑) 2017 Informa UK Limited, trading as Taylor \& Francis Group 
Rolland adds, moreover, that the 'rich and beneficent power' of the oceanic feeling is found both in the 'religious souls of the West ${ }^{5}$ and in the 'great minds of Asia." ${ }^{6}$ Significantly, he singles out 'two personalities' - the nineteenth-century Bengali mystic, Sri Ramakrishna (1836-1886), and his chief disciple, Swami Vivekananda (1863-1902) - who not only experienced this oceanic feeling but also 'revealed an aptitude for thought and action which proved strongly regenerating for their country and for the world. ${ }^{7}$ Indeed, Rolland was so fascinated by these two Indian spiritual personalities that he went on to write a three-volume work on them - Vie de Ramakrishna (1929), Vie de Vivekananda (1930), and L'Évangile universel (1930) - which he sent to Freud in 1930.

Freud, in turn, read Rolland's biographies of Sri Ramakrishna and Swami Vivekananda and commented on them in a letter to Rolland dated 19 January 1930. Freud also sent Rolland a copy of his book, Das Unbehagen in der Kultur (1930), the opening section of which investigates Rolland's notion of oceanic feeling from a psychoanalytic standpoint. In this book, Freud interprets the oceanic feeling as a regression to a pre-Oedipal feeling of unity with the external world, and he argues against Rolland - that the true source of religion is not this oceanic feeling but an infantile feeling of helplessness, which can be traced to the child's need for the father's protection. ${ }^{8}$

While Jeffrey Masson and David Fisher have defended Freud's psychoanalytic interpretation of the oceanic feeling as a regression to an infantile state, ${ }^{9}$ numerous scholars - including Janette Simmonds, William Meissner, David Werman, and William Parsons - have argued that Freud's psychoanalytic understanding of mystical experience is reductive and inaccurate. ${ }^{10}$ Werman, Parsons, and Jussi Saarinen have also fruitfully explored the unique phenomenology of Rolland's oceanic feeling. ${ }^{11}$

However, comparatively few scholars have investigated Rolland's underlying motivations for asking Freud to analyse the oceanic feeling in his fateful 1927 letter. Fisher and Parsons, who are among the few to have addressed this issue, simply assume that Rolland was expecting from Freud a nonreductive psychoanalytic examination of mysticism. ${ }^{12}$ I will argue, however, that Rolland's intentions in introducing the oceanic feeling to Freud were much more complex, multifaceted, and critical than scholars have generally assumed.

In Section I, I will examine Rolland's biographies of Sri Ramakrishna and Vivekananda, which provide essential clues to understanding the complex intentions behind his appeal to the oceanic feeling in his letter to Freud. In these biographies, Rolland not only polemicizes against psychoanalytic approaches to mystical experience but also encourages psychoanalysts to correct and deepen their superficial conception of the mind by taking seriously the mystical experiences of both Eastern and Western saints. I will argue that Freud's attempts to rebut some of Rolland's criticisms of

\footnotetext{
${ }^{5}$ For Rolland, these 'religious souls of the West' include Pseudo-Dionysius. See Romain Rolland, The Life of Vivekananda and the Universal Gospel, trans. E.F. Malcolm-Smith (Kolkata: Advaita Ashrama, 2008 [1931]) (hereafter LV), 291-318. Hereafter, whenever I refer to this book, I will make parenthetical citations in the body of the article, using the format '(LV, p.__).'

${ }^{6}$ Parsons, Enigma of the Oceanic Feeling, 173.

${ }^{7}$ Ibid.

${ }^{8}$ Sigmund Freud, Civilization and Its Discontents [The Standard Edition of the Complete Psychological Works of Sigmund Freud, Volume 21, trans. and ed. James Strachey (London: Hogarth Press, 1930), 59-145].

${ }^{9}$ See Jeffrey Masson, The Oceanic Feeling (Dordrecht: D. Reidel, 1980), 1-50, and David Fisher, 'Reading Freud's Civilization and Its Discontents,' in Modern European Intellectual History: Reappraisals and New Perspectives, ed. Dominick LaCapra and Stephen Kaplan (Ithaca: Cornell University Press, 1982).

${ }^{10}$ See Janette Graetz Simmonds, 'The Oceanic Feeling and a Sea Change: Historical Challenges to Reductionist Attitudes to Religion and Spirit From Within Psychoanalysis', Psychoanalytic Psychology 23, no. 1 (2006): 128-42; Parsons, Enigma of the Oceanic Feeling; William Parsons, "'Let Him Rejoice in the Roseate Light!": Teaching Psychoanalysis and Mysticism', in Teaching Freud, ed. Diane Jonte-Pace (New York: Oxford University Press, 2003), 79-99; W.W. Meisser, 'On Putting a Cloud in a Bottle: Psychoanalytic Perspectives on Mysticism', Psychoanalytic Quarterly 74 (2005): 507-59; David Werman, 'On the Nature of the Oceanic Experience', Journal of the American Psychoanalytic Association 34 (1986): 123-39; Roger Dadoun, 'Rolland, Freud, et la Sensation Océanique', Revue d'Histoire littéraire de la France 76, no. 6 (1976): 936-46; Erik Erikson, Young Man Luther: A Study in Psychoanalysis and History (New York: Norton, 1962 [originally published in 1958]); Joel Kovel, A Complete Guide to Therapy (Harmondsworth: Penguin, 1983 [originally published in 1976]).

${ }^{11}$ See Jussi Saarinen, 'The Oceanic State: A Conceptual Elucidation in Terms of Modern Contact', International Journal of Psychoanalysis 93 (2012): 939-61; Werman, 'On the Nature of the Oceanic Experience'; Parsons, Enigma of the Oceanic Feeling.

${ }^{12} \mathrm{See}$, for instance, David Fisher, 'Sigmund Freud and Romain Rolland: The Terrestrial Animal and His Great Oceanic Friend', American Imago 33 (1976): 1-59; Parsons, Enigma of the Oceanic Feeling, 14; Saarinen, 'The Oceanic State', 941.
} 
psychoanalysis are largely unconvincing. In Vie de Vivekananda, Rolland calls for a 'new science of the mind' rooted in the ancient Indian spiritual systems of Rāja-Yoga and Jñāna-Yoga. According to Rolland, this new science of the mind would incorporate some of the most valuable insights of psychoanalysis without succumbing to the reductionism prevalent in psychoanalytic approaches to mystical experience.

With this background in place, I will argue in Section II that Rolland's primary intentions in appealing to the oceanic feeling in his 1927 letter to Freud - intentions less evident in his letters to Freud than in his biographies of Sri Ramakrishna and Vivekananda - were twofold: first, to challenge the fundamental assumptions of psychoanalysis from a mystical perspective, and second, to confront Freud with a Yogic 'science of the mind' that he felt was superior to Freud's psychoanalytic science.

In Section III, I will consider Parsons' influential thesis that Rolland's critical engagement with Freud anticipated what Parsons calls the 'adaptive' and 'transformative' psychoanalytic approaches to mysticism that emerged after Freud's time. Drawing on the arguments of Sections I and II, I will argue that Parsons' genealogy of Rolland's legacy is incomplete and somewhat misleading, since it downplays Rolland's radical critique of psychoanalysis. Against Parsons, I will argue that Rolland's pioneering criticisms of psychoanalysis from a mystical perspective anticipated certain aspects of the critiques of psychoanalysis developed by twentieth-century mystics as diverse as Sri Aurobindo, Swami Akhilananda, and Ken Wilber.

\section{Rolland's views on psychoanalysis and mysticism in his biographies of Sri Ramakrishna and Vivekananda}

Rolland's biographies of Sri Ramakrishna and Vivekananda provide helpful insight into Rolland's complex views on both psychoanalysis and mysticism. ${ }^{13}$ Throughout Vie de Ramakrishna, Rolland conspicuously refrains from indulging in psychoanalytic interpretations of the life and teachings of Sri Ramakrishna. ${ }^{14}$ To mention just a few examples, Rolland approvingly refers to Sri Ramakrishna's teaching that '[a]bsolute continence must be practised if God is to be realized.' ${ }^{35}$ While psychoanalytic commentators such as Jeffrey Masson, Narasingha Sil, and Jeffrey Kripal have claimed that sexual repression plays a crucial explanatory role in Sri Ramakrishna's behaviour and spiritual experiences, Rolland explicitly rejects the psychoanalytic theory of repression in the case of mystics. ${ }^{16}$ According to Rolland, both Sri Ramakrishna and Vivekananda successfully observed absolute 'sexual continence' in thought, word, and deed. ${ }^{17}$ Indeed, Rolland claims that mystics, by means of the practice of absolute continence, are able to sublimate - rather than repress - their sexual energies and rechannel them toward spiritual ends. ${ }^{18}$ As Rolland puts it,

\footnotetext{
${ }^{13}$ For biographical information about Sri Ramakrishna and Vivekananda, Rolland consulted numerous people, including Swami Shivananda, Swami Ashokananda, Mahendra Nath Gupta, Josephine MacLeod, Dhan Gopal Mukherji, and Kalidas Nag. See Romain Rolland, The Life of Ramakrishna, trans. E.F. Malcolm-Smith (Kolkata: Advaita Ashrama, 2007 [French original published in 1929]), ix. Rolland drew heavily on two source-texts on Sri Ramakrishna: Swami Saradananda, Sri Ramakrishna: The Great Master, 2 vols., trans. Swami Jagadananda (Mylapore, Madras: Ramakrishna Math, 1920), and Max Müller, Ramakrishna: His Life and Sayings (London: Longmans, 1898). Rolland also consulted Sister Christine's unpublished memoirs of Vivekananda (The Life of Ramakrishna, ix).

${ }^{14}$ Rolland's second appendix to LV - which I discuss at length later in this section - indicates two main reasons why Rolland avoids a psychoanalytic framework when discussing Sri Ramakrishna. First, Rolland is generally sceptical of many of the key assumptions of psychoanalytic theory. Second, Rolland argues that a psychoanalytic framework is especially reductive when applied to mystics.

${ }^{15}$ Rolland, The Life of Ramakrishna, 153.

${ }^{16}$ See Masson, The Oceanic Feeling; Narasingha Sil, Rāmakrșna Paramahamsa: A Psychological Profile (Leiden: E.J. Brill, 1991); and Jeffrey Kripal, Kali's Child: The Mystical and the Erotic in the Life and Teachings of Ramakrishna (Chicago: University of Chicago Press, 1995).

${ }^{17}$ Rolland, The Life of Ramakrishna, 153.

${ }^{18}$ Rolland's understanding of the spiritual sublimation of sexual energy likely derives from the teachings of Sri Ramakrishna and Vivekananda. Rolland cites Sri Ramakrishna's teaching that the long-term practice of continence results in the development of a 'new nerve ... called "the nerve of intelligence"' (The Life of Ramakrishna, 153). Rolland also carefully read Vivekananda's
} 
All great mystics and the majority of great idealists, the giants among the creators of the spirit, have clearly and instinctively realized what formidable power of concentrated soul, of accumulated creative energy, is generated by a renunciation of the organic and psychic expenditure of sexuality. ${ }^{19}$

Psychoanalytic commentators have had a field day with Sri Ramakrishna's femininity and crossdressing, some going so far as to claim that Sri Ramakrishna was a closet homosexual. ${ }^{20}$ Rolland, by contrast, refers several times to Sri Ramakrishna's 'femininity ${ }^{21}$ and 'feminine grace, ${ }^{, 2}$ but he views Sri Ramakrishna's femininity not as psychoanalytic fodder but as a distinctive and charming personality trait. The psychoanalyst Masson is clearly disappointed - even piqued - that Rolland did not consider Sri Ramakrishna to be a repressed homosexual: 'It is astonishing that Romain Rolland could so overlook the blatant homosexual concerns of Ramakrishna. On the contrary, he seemed to perceive these elements as a sign of deep psychological penetration. ${ }^{, 23}$ Rolland's reverential account of Sri Ramakrishna's pure and utterly unworldly marriage to the young Sarada Devi is equally devoid of any psychoanalytic agenda: 'It was a union of souls and remained unconsummated ... and later it became a beautiful thing. A tree must be judged by its fruits, and in this case the fruits were of God, pure and not carnal love. ${ }^{24}$ Moreover, in his discussion of Sri Ramakrishna's first vision of Kālī, Rolland quotes Sri Ramakrishna's own vivid description of his vision, in which he reports that he 'saw an ocean of the Spirit, boundless, dazzling' and that he 'was conscious of the presence of the Divine Mother. ${ }^{25}$ Rolland notably refrains from psychoanalysing Sri Ramakrishna's oceanic experience, in spite of Sri Ramakrishna's references to oceanic imagery and the 'Mother,' which could easily lend themselves to a psychoanalytic interpretation (as Rolland himself was well aware). ${ }^{26}$

Evidently, throughout his biographies, Rolland consciously refrains from invoking psychoanalytic theories and categories - such as sexual repression, the Oedipus complex, and latent homosexuality to explain the behaviour of Sri Ramakrishna and Vivekananda. ${ }^{27}$ Moreover, in the second appendix to his biography of Vivekananda, entitled 'On Mystic Introversion and Its Scientific Value for Knowledge of the Real,' Rolland attacks psychoanalytic approaches to mystical experience and argues that 'mystic introversion' is a valid scientific 'method of experiment' (LV, p. 284). The Appendix focuses on Ferdinand Morel's Essai sur l'Introversion mystique (1918), a psychoanalytic investigation of the mystical experiences of Pseudo-Dionysius and other mystics. Rolland not only points

Raja-Yoga, which provides a detailed account of the yogic process by which 'sex energy,' when 'checked and controlled,' gets converted into 'Ojas,' the source of spiritual strength and power. See The Complete Works of Swami Vivekananda: Mayavati Memorial Edition, vol. 1 (Kolkata: Advaita Ashrama, 2007 [1907]), 169-70.

${ }^{19}$ For Rolland, these 'great idealists' include Ludwig von Beethoven, Honoré de Balzac, and Gustave Flaubert (The Life of Ramakrishna, 152)

${ }^{20}$ See, for instance, Masson, The Oceanic Feeling; Sil, Rāmakrsna Paramahamsa; and Kripal, Kali's Child.

${ }^{21}$ Rolland, The Life of Ramakrishna, 9.

${ }^{22}$ Ibid., 6.

${ }^{23}$ Masson, The Oceanic Feeling, 46 n. 9.

${ }^{24}$ Rolland, The Life of Ramakrishna, 21.

${ }^{25}$ Ibid., 15.

${ }^{26}$ Rolland explicitly discusses the psychoanalytic interpretation of mystical tropes such as the ocean and the Mother in LV, $281-2$.

${ }^{27}$ In his preface 'To My Eastern Readers,' Rolland indicates that throughout his biographies of Sri Ramakrishna and Vivekananda, he has adopted an attitude of hermeneutic sympathy and immanence tempered by critical judgement. As he puts it,

The only thing to which I can testify is the sincerity which has led me to make a pious attempt to enter into all forms of life. At the same time I must confess that I have not abdicated one iota of my free judgment as a man of the West. (The Life of Ramakrishna, xiii)

As he points out, he sees in Sri Ramakrishna 'a man and not an "Incarnation" as he appears to his disciples' (The Life of Ramakrishna, xiii). Rolland also apologizes in advance for the 'mistakes' he might have made in his biographies, acknowledging the extreme difficulties involved in a Westerner's attempt to understand the mindset of Indian saints:

In spite of all the enthusiasm I have brought to my task, it is impossible for a man of the West to interpret men of Asia with their thousand years' experience of thought; for such an interpretation must often be erroneous. (The Life of Ramakrishna, xiii)

It is worth noting that Rolland exhibits greater awareness of the dangers of ethnocentric prejudice and bias than some contemporary scholars writing on Sri Ramakrishna - such as Kripal, Masson, and Sil - who do not reflect adequately on their own cultural situatedness. 
out the 'weak points' in Morel's arguments but also makes more sweeping criticisms of psychoanalytic approaches to mysticism in general, three of which are especially significant (LV, p. 278). ${ }^{28}$

First, Rolland claims that psychoanalysts tend to lack the spiritual sensibility, sympathy, and open-mindedness needed for an adequate understanding of religious experience:

The intuitive workings of the 'religious' spirit ... have been insufficiently studied by modern psychological science in the West and then too often by observers who are themselves lacking in every kind of 'religious' inclination, and so are ill equipped for the study, and involuntarily prone to depreciate an inner sense they do not themselves possess. (LV, p. 277)

According to Rolland, psychoanalysts have tended to 'depreciate' the mystical experiences of saints because the psychoanalysts themselves lack the 'inner sense' necessary to have mystical experiences in the first place. ${ }^{29}$ Interestingly, in a letter to Rolland dated 20 July 1929, Freud admits, 'To me mysticism is just as closed a book as music. ${ }^{30}$ Four days later, Rolland responds to Freud: 'I can hardly believe that mysticism and music are unknown to you. Because "nothing human is unknown to you." Rather, I think that you distrust them, because you uphold the integrity of critical reason, with which you control the instrument. ${ }^{31}$ This epistolary exchange helps clarify Rolland's understanding of Freud's stance toward mysticism: in Rolland's view, while Freud does possess a capacity for mystical intuition, Freud's 'critical reason' makes him suspicious of this mystical 'inner sense' both in himself and in others. In any case, Rolland's main point is that if a psychoanalyst - for whatever reason - has a dogmatic prejudice against the validity of mystical knowledge, then the psychoanalyst's analysis of mystical experience is doomed to be biased and unreliable.

At various points in the Appendix, Rolland makes the provocative suggestion that the psychoanalytic denigration of mystical experience stems from an abnormally extroverted tendency among psychoanalysts themselves. Morel, as Rolland notes, borrows the term 'introversion' from C.G. Jung but expands its meaning to encompass what he calls 'mystic introversion' (LV, p. 277 fn. 2). Rolland, in turn, departs from both Jung and Morel in accusing many psychoanalysts - including Freud, Morel, Janet, and Ribot - of 'extroversion' in the normative sense of having a pathological aversion to, or incapacity for, introversion. According to Rolland, psychoanalytic extroverts dogmatically ascribe 'the highest rank to "interested" action and the lower rank to concentration of thought' (LV, p. 279). Indeed, Rolland turns the tables on psychoanalysts by pathologizing their own tendency toward extroversion: 'And this depreciation of the most indispensable operation of the active mind - the withdrawal into oneself, to dream, to imagine, to reason - is in danger of becoming a pathological aberration. The irreverent observer is tempted to say, "Physician, heal thyself!" (LV, p. 279).' If psychoanalysts have tended to dismiss allegedly mystical experiences as pathological aberrations, Rolland suggests that the deep-seated aversion to introversion among many psychoanalysts is itself a 'pathological aberration.'

To illustrate this point, Rolland refers specifically to Janet's privileging of the 'function of the real,' the 'awareness of the present, of present action, the enjoyment of the present' (LV, p. 279). According to Rolland, Janet places the 'whole world of imagination and fancy' at 'the bottom of the scale' (LV, p. 279). Rolland goes on to detect a similar denigration of introversion in the work of Freud and Bleuler and adds a revealing footnote in which he invokes Plotinus: "With quite unconscious irony a great "introvert" like Plotinus sincerely pities the "extroverts," the "wanderers outside

\footnotetext{
${ }^{28}$ An anonymous referee asks me to clarify how my analysis of Rolland's criticisms of psychoanalysis differs from Parsons' analysis in Enigma of the Oceanic Feeling, 61-73. According to Parsons, Rolland was highly critical of what he took to be reductive psychoanalytic approaches to mysticism - such as those of Freud and Morel - but quite open and even sympathetic to non-reductive psychoanalytic approaches to mysticism. Indeed, Parsons is eager to show that Rolland did not harbor 'active hostility toward psychoanalytic modes of investigation' (Enigma of the Oceanic Feeling, 156). By contrast, I will argue in this section that Rolland was actively hostile towards psychoanalytic investigations of mysticism. Moreover, I hope to show that Rolland's criticisms of psychoanalysis are so fundamental and far-reaching that they impugn even the 'adaptive' and 'transformative' psychoanalytic approaches that Parsons thinks Rolland advocates.

${ }^{29}$ By 'inner sense,' Rolland seems to mean a faculty for mystical knowledge.

${ }^{30}$ Parsons, Enigma of the Oceanic Feeling, 175.

${ }^{31}$ Parsons, Enigma of the Oceanic Feeling, 176.
} 
themselves" (Ennéades IV, III [17]), for they seem to him to have lost the "function of the real"' (LV, p. 279). In this passage from the Enneads, Plotinus refers to people who are so obsessed with their physical body that they have forgotten their divine soul within. ${ }^{32}$ Rolland cleverly appropriates this passage from Plotinus in the service of a spiritual metacritique of psychoanalysis. Inhabiting Plotinus' mystical standpoint, Rolland argues that psychoanalysts have a severely impoverished understanding of what counts as 'real,' since they tend to dismiss spiritual entities such as the soul or God - which mystics such as Plotinus take to be the Ultimate Reality - as merely subjective imaginings. ${ }^{33}$ According to Rolland, the tendency among psychoanalysts to denigrate mystical experience stems from their pitiable - indeed, pathological - extroversion, which leads them to favour action in, and adaptation to, the external world over concentration, thought, and spiritual contemplation.

Later in the Appendix, Rolland suggests that another reason for the psychoanalytic denigration of introversion is the assumption of a false dichotomy between introversion and extroversion: many psychoanalysts wrongly assume that the mystic's preoccupation with inward states comes at the expense of his or her adaptation to external reality. Rolland states:

\begin{abstract}
If a scientist maintains that such a knowledge [i.e. the mystic's knowledge] of psychic profundities teaches us nothing about exterior realities, he is really, though perhaps unwittingly, obeying a prejudice of proud incomprehension as one-eyed as that of religious spiritualists who set up an insurmountable barrier between spirit and matter. (LV, p. 283)
\end{abstract}

Once again, Rolland turns the psychoanalytic hermeneutics of suspicion against the psychoanalysts themselves by diagnosing them with an unconscious 'prejudice' that prevents them from recognizing the compatibility of mystic introversion with an ability to flourish in the external world. Rolland singles out Vivekananda as a perfect example of a great mystic who was fully capable of dynamic action in the world:

A great 'Introvert' will know at the same time how to be a great 'Extrovert.' Here the example of Vivekananda seems to me to be conclusive. Interiorization has never led in principle to diminution of action. (LV, p. 287)

Rolland argues that the compatibility of introversion and extroversion finds its ultimate philosophical justification in the Vedāntic view - to which he clearly subscribes - that the Reality known through mystic introspection is identical with the Reality underlying the external world. As Rolland puts it, 'The laws of the inner psychic substance are of necessity themselves those of outside reality' (LV, p. 284). Hence, from Rolland's Vedāntic perspective, the psychoanalytic denigration of mysticism is rooted in the erroneous metaphysical assumption of a dichotomy between inner and outer, which can itself be traced to a pathological aversion to introversion.

After Freud read Rolland's biographies of Sri Ramakrishna and Vivekananda, Freud wrote a letter to Rolland dated 19 January 1930, in which he objects to Rolland's use of the terms 'introvert' and 'extrovert':

the distinction between extrovert and introvert derives from C.G. Jung, who is a bit of a mystic himself and hasn't belonged to us for years. We don't attach any great importance to the distinction and are well aware that people can be both at the same time, and usually are. ${ }^{34}$ emphasis in the original

Freud attempts to dodge Rolland's criticisms of psychoanalysis by claiming that Jung, and not Freud himself, uses the terms 'extroversion' and 'introversion' and assumes a sharp dichotomy between them. Freud's response to Rolland, however, is clearly beside the point, since Rolland consciously expands the meaning of the terms 'introversion' and 'extroversion' well beyond Jung's understanding of the terms. The metacritical thrust of Rolland's appropriation of the originally Jungian terms is entirely lost on Freud. For Rolland, psychoanalysts as diverse as Freud, Janet, Morel, and Bleuler

\footnotetext{
${ }^{32}$ See Plotinus, Enneads, vol. 4, trans. A.H. Armstrong (Cambridge, MA: Harvard University Press, 1984), 87-91.

${ }^{33}$ Rolland refers to Plotinus at various points in The Life of Ramakrishna. See, for instance, 144, 285,315 n., 226 n., 297 , and 311 n. Most significantly, Rolland devotes four pages of Note III to a laudatory discussion of Plotinus' mystical philosophy and its affinities with Indian thought (The Life of Ramakrishna, 295-9).

${ }^{34}$ Parsons, Enigma of the Oceanic Feeling, 176.
} 
are 'extroverts' in Rolland's broader sense of the term, since they all tend to denigrate the existential import and value of mystical experience.

Rolland's second criticism of psychoanalysis in the Appendix, which is intimately related to the first criticism, is that psychoanalysts tend to adopt reductive views on mystical experience as a result of their preconceived ideas. Rolland declares:

You, doctors of the Unconscious, instead of making yourselves citizens of this boundless empire and possessing yourselves of it, do you ever enter it except as foreigners, imbued with the preconceived idea of the superiority of your own country and incapable of ridding yourselves of the need, which itself deforms your vision, of reducing whatever you catch a glimpse of in this unknown world to the measure of the one already familiar to you? (LV, p. 283)

According to Rolland, psychoanalysts enter the 'boundless empire' of mystical experience as 'foreigners,' because they are unable, or unwilling, to understand mystical experience on its own terms and instead analyse mystical experience in terms of their own stock psychoanalytic ideas and assumptions. From Rolland's perspective, perhaps the most fundamental preconception among psychoanalysts is their borderline-pathological prejudice against introversion - targeted by Rolland's first criticism - which leads them to dismiss or downplay the metaphysical and salvific claims of mystics.

Another preconceived idea discussed at length by Rolland in the Appendix is the idea of regression:

Almost all psychologists are possessed by the theory of Regression, which appears to have been started by Th. Ribot. It is undoubtedly a true one within the limited bounds of his psychopathological studies on functional disorganization, but it has been erroneously extended to the whole realm of the mind, whether abnormal or normal. (LV, p. 278)

According to Rolland, the tendency among psychoanalysts to interpret mystical experience as a regression to an infantile state is highly questionable. While Rolland concedes that the theory of regression is often applicable to cases of psychological abnormality or pathology, he claims that psychoanalysts are not justified in applying the theory of regression to mystics, who do not exhibit pathological behaviour. ${ }^{35}$ From Rolland's perspective, psychoanalysts favour such a regressive explanation of mystical experience in part because of their own preconceived preference for the theory of regression. ${ }^{36}$

Interestingly, however, Rolland does admit that certain features of mysticism might appear to 'add weight' to the psychoanalyst's assumption that mystic introversion is 'a return to a primary stage, to an intrauterine state' (LV, p. 281). First, the 'symbolic words' used by mystics such as Eckhart and Tauler to describe their spiritual experiences - such as 'Grund,' 'Urgrund,' and 'Wurzel' - often suggest, at least superficially, a return to a primordial condition. Second, the psychoanalytic explanation of mystical experience in terms of regression might help explain the 'curious instinct which has given birth in Ramakrishna's India to the passionate worship of the Mother, and in Christianity to that of the Virgin Mother' (LV, p. 281). Rolland makes the subtle point, however, that while mystical experiences do undoubtedly bear a superficial resemblance to infantile states, there is, in reality, a world of difference between them phenomenologically. Accordingly, Rolland invokes the distinction drawn by Henri Bergson’s disciple, Édouard Le Roy, between the pre-discursive intuition of the infant and the post-discursive intuition of the mystic. Le Roy contrasts the 'simplicity anterior to the discursive intricacy, belonging solely to the confused pre-intuition of a child' with the mystic's 'rich and luminous simplicity, which achieves the dispersion of analysis by surpassing and overcoming it' (LV, p. 282 fn. 10). Misled by the superficial similarity of these two entirely different states,

\footnotetext{
${ }^{35}$ See also LV, p. 151 fn. 19.

${ }^{36}$ As Parsons convincingly points out, Rolland himself can be charged with holding the preconceived perennialist view that all mystical experience is essentially the same oceanic feeling. See Parsons, Enigma of the Oceanic Feeling, 116-19. I agree with Parsons that Rolland's perennialism prevents him from honouring the specificity and uniqueness of the various kinds of mystical experiences in different religious traditions.
} 
psychoanalysts have tended mistakenly to reduce the post-discursive 'simplicity' of mystical experience to the pre-discursive 'simplicity' of infantile experience.

In his letter to Rolland, Freud protests: 'our terms such as regression, narcissism, pleasure principle are of a purely descriptive nature and don't carry within themselves any valuation. ${ }^{, 37}$ Once again, however, Freud's attempt to sidestep Rolland's criticisms proves to be facile and unconvincing. First of all, at certain places in his work, Freud's use of the concept of regression does have a strongly normative thrust. For instance, in Das Unbehagen in der Kultur, Freud's brusque dismissal of religion as a regression to an infantile state is flagrantly normative:

The whole thing is so patently infantile, so foreign to reality, that to anyone with a friendly attitude to humanity it is painful to think that the majority of mortals will never be able to rise above this view of life. ${ }^{38}$ emphasis in the original

No wonder Rolland is so scathing in his attack on the scientific pseudo-objectivity of psychoanalysis: while psychoanalysts pretend to be objective and non-normative in their diagnoses and explanations, their supposedly objective judgments often stem from profoundly subjective prejudices. Secondly, even if Freud's concept of regression is non-normative, it remains vulnerable to Rolland's two basic criticisms: first, that the concept is extended illegitimately from abnormal cases to the cases of mystics; second, that infantile states and mystical experiences, in spite of certain superficial resemblances, are radically different states. Hence, it must be said that Freud's response to Rolland's criticisms of psychoanalysis is superficial and inadequate.

In earlier letters written to the Swiss psychoanalyst Charles Baudouin in 1922, Rolland also repeatedly singled out for attack the psychoanalytic theory of infantile sexuality. In one letter, Rolland writes: 'I'm speaking to you, my friend, in all affectionate candor: nothing seems more false and revolting to me than this obsession - not in the child but imputed to him - with sexual things. ${ }^{39}$ In another letter, Rolland scathingly remarks: 'Whatever he [the child] says, writes or draws, you are ready to reduce it to three or four motifs: Oedipus or Electra complex, sexual themes, etc .... But it is you, the psychoanalysts, who are obsessed with all this. ${ }^{40}$ Although Rolland does not explicitly target the psychoanalytic theory of infantile sexuality in his Appendix on Morel, it is clear from his earlier letters that one of the 'preconceived' ideas held by psychoanalysts that Rolland rejected is the theory of infantile sexuality, particularly the Oedipus Complex.

Rolland's third fundamental criticism of psychoanalysis in the Appendix stems from his previous two criticisms. As a result of their bias against mystical experience, psychoanalysts have, at best, an incomplete knowledge of the workings of the mind. Rolland quotes a passage from Morel's book that discusses Pseudo-Dionysius' mystical experience of Unity: 'Consciousness seems to gather itself together to confine itself within some unknown psychic pineal gland and to withdraw into a kind of centre wherein all organic functions and all psychic forces meet, and there it enjoys Unity ... nothing else' (LV, p. 282). From Morel's psychoanalytic perspective, Pseudo-Dionysius' experience is purely subjective and hence has no metaphysical import: the 'Unity' the mystic enjoys, according to Morel, is not a unity with God or the cosmos so much as a regression to a feeling of infantile unity with the external world. Accordingly, Rolland faults Morel for failing to take seriously the metaphysical dimension of Pseudo-Dionysius' mystical experience:

\footnotetext{
'Nothing else?' - What more do you want? There, according to your own admission, you have an instrument for penetrating to the depths of functional consciousness, of subliminal life - and yet you do not use it in order to complete your knowledge of the whole activity of the mind. (LV, p. 282)
}

From Rolland's perspective, the psychoanalytic understanding of the unconscious remains superficial, since it fails to acknowledge what Rolland takes to be the most archaic metaphysical layer

\footnotetext{
${ }^{37}$ Parsons, Enigma of the Oceanic Feeling, 176.

${ }^{38}$ Freud, Civilization and Its Discontents, 74.

${ }^{39}$ Cited in David Werman, 'Sigmund Freud and Romain Rolland', International Review of Psychoanalysis 4 (1977): 230.

${ }^{40}$ Cited in Werman, 'Sigmund Freud and Romain Rolland', 230.
} 
of the unconscious - namely, the 'Ocean of Being' which unites us all (LV, p. 227). According to Rolland, since mystics have directly experienced this oceanic substratum of the unconscious, psychoanalysts stand to learn a great deal from the experiences of mystics. Hence, Rolland encourages psychoanalysts to leave off trying to psychoanalyse mystics and to attempt, rather, to learn from mystics in order to enrich and deepen their understanding of the psyche and its metaphysical depths. ${ }^{41}$

In fact, toward the end of the Appendix, Rolland goes so far as to suggest that mystic introversion is a valid scientific procedure that gives the investigator access to aspects of the mind not detectable or measurable by any other empirical means. As Rolland puts it,

the judicious use of deep introversion opens to the scientist unexplored resources: for it constitutes a new method of experiment, having the advantage that the observer identifies himself with the object observed the Plotinian identity of the seer and the thing seen. (LV, pp. 284-5)

From Rolland's perspective, the very fact that mystic introversion is 'subjective' - far from making it un-scientific - makes it especially suited to serve as a rigorously scientific 'method of experiment.' There is less of a chance of investigative error or misinterpretation, Rolland argues, because the 'seer' and the 'thing seen' are identical in mystic introversion.

That this remark is directed against psychoanalysts is abundantly clear from the context, since Rolland goes on to attack the 'exclusive rationalists, and particularly ... psycho-pathologists' - he even mentions Freud by name - who reject this 'great effort' to incorporate mystic introversion into scientific investigation (LV, p. 286). For Rolland, the positivistic rationalism of psychoanalysts leads them to adopt an unjustifiably narrow view of science, which dogmatically excludes the possibility that mystic introversion is a genuinely scientific method of gaining knowledge. ${ }^{42}$

In a long footnote at the end of his chapter, 'The Great Paths: The Four Yogas,' Rolland calls for a 'new science of the mind' (une nouvelle science de l'esprit) which would be far better equipped than psychoanalysis to determine the nature and existential value of mystical experiences:

How is it possible to estimate the value of such [religious] experiences? Perhaps by a new science of the mind, armed with a more supple, and finer instrument of analysis than the incomplete rough methods of the psychoanalyst and his fashionable descendants. ${ }^{43}$ (LV, pp. $\left.212-13 \mathrm{fn} .120\right)$

Unfortunately, Rolland does not explicitly discuss this 'new science of the mind' anywhere else in the book. Nonetheless, numerous passages from the long chapter in which this footnote occurs provide important clues as to what Rolland meant. In this chapter, Rolland summarizes Vivekananda's account of the four main Yogas (spiritual practices) that lead to spiritual realization: namely, Karma Yoga (the Yoga of Works), Bhakti Yoga (the Yoga of Love), Rāja Yoga (the Yoga of Concentration), and Jñāna Yoga (the Yoga of Knowledge). At various points in this chapter, Rolland suggests that the disciplines and methods of Rāja Yoga and Jñāna Yoga in particular should serve as the basis for the 'new science of the mind' he envisions. However, he also insists on the need to modify and update these ancient Indian Yogic practices in the light of modern scientific findings - a project, Rolland believes, that was initiated by Vivekananda and continued by Sri Aurobindo.

According to Vivekananda, Rajja Yoga is the science of concentration based on the principles outlined in Patañjali's Yogasūtra. Rolland elegantly defines Rāja Yoga as 'a minutely elaborated and experimental science for the conquest of concentration and mastery of the mind' (LV, p. 184). Rolland goes on to summarize the 'astâningayoga' ('eight-limbed discipline'), which lies at the heart of Patañjali's system, as explained by Vivekananda: 1. yama (restraint), 2. niyama (observance), 3. àsana (physical posture), 4. prānāyāma (regulation of breath), 5. pratyāhāra (sense-restraint), 6. dhāraña (mental fixity), 7. dhyāna (sustained concentration), and 8. samādhi (perfect concentration). Rolland specifies the five practices involved in the first stage of yama: 1 . non-injury toward

\footnotetext{
${ }^{41}$ Rolland seems to imply that psychoanalysts can learn especially from the testimony and teachings of mystics, even if psychoanalysts have not enjoyed any mystical experiences themselves.

${ }^{42}$ For a helpful discussion of Rolland's critique of Freud's positivism, see Dadoun, 'Rolland, Freud, et la Sensation Océanique', 942.

${ }^{43}$ For the original French passage, see Romain Rolland, La Vie de Vivekananda; et, L'évangile universel (Paris: Stock, 1930 ), 98 fn. 1.
} 
all creatures (which he calls the 'great aim of Gandhi'), 2. absolute truthfulness in 'action, word, thought,' 3. perfect chastity and purity, 4. absolute non-covetousness, and 5. purity of soul and absolute disinterestedness (LV, p. 186). Rolland approvingly refers to these five preliminary ethical disciplines as a 'fivefold ring of fire,' the 'five indispensable conditions,' each one of which is 'sufficient to make a saint' (LV, p. 186). He notes that the third and fourth limbs of the aștàngayoga - āsana and prānāyāma - are 'exercises of a physiological nature ... of great interest to medical science' (LV, p. 191 fn. 73).

Rolland then goes on to focus on the remaining four limbs of the astângayoga, the 'three first psychological stages in the concentration of the mind' (pratyāhāra, dhāraṇā, and dhyāna) which culminate in the coveted state of samädhi (LV, p. 192). He is especially impressed with Vivekananda's ingenious elaboration of the technique of pratyāhāra, by means of which - according to Rolland the mind grows quiet 'under the calm inner regard that judges it impartially' (LV, p. 192). Rolland then archly observes, 'The ancient Yogis did not wait for Dr. Freud to teach them that the best cure for the mind is to make it look its deeply hidden monsters straight in the face ...' (LV, p. 192). In the final footnote in his section on Rāja Yoga, Rolland strikingly declares that it has actually been proved [by Rāja Yoga] that sovereign control of the inner life is able to put into our hands (partially if not entirely) our unconscious or subconscious life' (LV, p. 194 fn. 79). Rolland then approvingly cites Vivekananda's statement from his book, Raja-Yoga: 'Almost every action of which we are now unconscious can be brought to the plane of consciousness' (LV, p. $194 \mathrm{fn} .79$ ). According to Rolland, the ancient Rāja Yogic method of detached mindfulness and mental concentration - especially as elaborated and amplified by the modern Yogic master Vivekananda - is a much safer, more effective, and more ethically and spiritually beneficial means of discovering and dissolving one's own unconscious complexes than Freudian psychoanalysis. Moreover, Rolland clearly felt that modern psychologists such as Freud could stand to learn a great deal from the psychological techniques of Rāja Yoga: 'I recommend it [Rāja Yoga] to Western masters of the new psychology and of pedagogy, in so far as it is scientifically founded on the physiology of the mind' (LV, p. 191).

Rolland points out that the various disciplines of Rajja Yoga should culminate in 'absolute Concentration,' which he characterizes as the 'most perfect instrument of scientific method' (LV, p. 187). Rolland goes on to add:

And in this we are all interested. Whatever may be the effect upon the mind produced by this instrument on the part of the Hindu seekers after truth, all seekers after truth, whether of the West or the East, are obliged to use that instrument; and it is to their advantage that it should be as exact and perfect as possible. There is nothing of the occult in it. (LV, p. 187)

Rolland makes abundantly clear here that the 'new science of the mind' he envisions would have as its chief 'instrument' the technique of mental concentration taught by the ancient Indian science of Rāja Yoga. Indeed, Rolland seems to have Freud - among others - in mind when he encourages Western scientists to acquaint themselves with, and learn from, the fundamental Rāja Yogic 'methods of control and mastery' of the mind:

It makes it all the more astonishing that Western reason has taken so little into account the experimental research of Indian Raja-Yogis, and that it has not tried to use the methods of control and mastery, which they offer in broad daylight without any mystery, over the one infinitely fragile and constantly warped instrument that is our only means of discovering what exists. (LV, p. 189)

From Rolland's perspective, the ancient psychological science of Rāja Yoga offers a far more sophisticated, comprehensive, and rigorously worked out account of the mind and its workings than even the most advanced Western psychologies, including psychoanalysis.

In sum, I would suggest that three features of Rāja Yoga in particular led Rolland to champion Rāja Yoga as the basis for a 'new science of the mind.' First, Rāja Yoga insists on the development of a strong moral character and numerous ethical qualities - such as non-injury, sexual purity, truthfulness, and unselfishness - as an indispensable precondition for the practice of mental control and mastery. By insisting on the inseparability of scientific investigation from ethical living, Rolland 
counters the pervasive Western assumption that science and ethics are independent enterprises. Second, since Rajja Yoga teaches psychological techniques that allow one to gain control and mastery of one's own mind, it is far more empowering and strength-giving than Western psychological methods that depend heavily on the curative role of the analyst. Third, since the fundamental principles and techniques on which Rāja Yoga is based were scientifically developed and empirically tested, Rolland believes that Rāja Yoga is in perfect consonance with the modern scientific temper of the West.

Rolland credits Vivekananda with inaugurating the urgent project of updating and modifying the techniques and findings of Rāja Yoga in the light of modern science:

While admitting, with no possibility of contradiction, that Yogist psycho-physiology uses explanations - and still more terms - that are both controvertible and obsolete, it should be easy to rectify them by readjusting

(as Vivekananda tried to do) the experiments of past centuries to modern science. (LV, p. 189)

Moreover, Rolland credits Sri Aurobindo with going 'one step further' (LV, p. 204 fn. 104) than Vivekananda by incorporating 'religious intuition' into 'the strict limits of science' (LV, p. 205 fn 104). Hence, for Rolland, Vivekananda and Sri Aurobindo - rather than Freud and other Western psychologists - are the true pioneers in the effort to develop a 'new science of the mind.'

Rolland claims, however, that the 'practical methods' (LV, p. 199) of Rāja Yoga must be combined with the Vedāntic philosophical method of Jñāna Yoga, the spiritual practice of self-inquiry that culminates in the realization of the 'innermost core of the soul' (au noyau le plus intime de l'âme) (LV, p. 203). ${ }^{44}$ Quoting Vivekananda, Rolland asserts that the Jñāna Yogĩ realizes 'an Abstract Essence underlying every existence,' which Rolland calls 'one Unity' (LV, p. 206). Crucially, since there is only one metaphysical Reality, the Jñāna Yogi discovers 'that at the innermost core of the soul' is 'the centre of the whole universe' (LV, p. 203). Rolland provides here the Vedantic rationale for his claim in the Appendix on Morel - against psychoanalytic orthodoxy - that mystic introversion is compatible with dynamic action in the world. According to Rolland, the method of introversion employed in Rāja Yoga and Jñāna Yoga is not merely 'subjective,' since the deepest core of our subjectivity is identical with the deepest core of the universe.

For Rolland, it is precisely this fundamental Vedāntic insight into the unity of everything that provides the metaphysical basis for the 'new science of the mind' he envisions (LV, p. 214). Accordingly, Rolland claims that 'Vedantic Advaitism' is 'so close to the aim of pure Science that they can hardly be distinguished' (LV, p. 206). Rolland continues:

The main difference is in the gesture with which the runners arrive at the tape: Science accepts and envisages Unity [l'Unité] as the hypothetical term for its stages of thought, giving them their right bearings and coordinating them. Yoga embraces Unity and becomes covered with it as with ivy. But the spiritual results are practically the same. (LV, p. 206)

For Rolland, while modern science is only able to posit 'Unity' as a hypothesis that has not yet been conclusively proved, Vedāntic Yoga teaches the psychological and rational methods for attaining the direct spiritual experience of this Unity at the core of our being. In the following chapter on 'The Universal Science-Religion,' Rolland elaborates how this Vedāntic realization of the 'Ocean of Being' (l'Etre océanique) also serves as the basis of 'the highest code of ethics: "Not me, but thou!"' (LV, pp. 227-8). ${ }^{45}$ As Rolland points out, both Sri Ramakrishna and Vivekananda experienced this oceanic feeling of the metaphysical Unity of everything. Rolland accordingly cites Vivekananda's reference to 'the vision of Self which penetrates all living beings' (LV, p. 228). And in his biography of Sri Ramakrishna, Rolland interprets Sri Ramakrishna’s first vision of the Divine Mother Kălī as the spiritual realization of the all-pervading 'Ocean' of Being: 'he saw nothing, but ... he was aware of Her all-permeating presence. He called the Ocean by Her name. ${ }^{\text {'4 }}$

\footnotetext{
${ }^{44}$ For the original French phrase, see Rolland, La Vie de Vivekananda, 86.

${ }^{45}$ For the original French, see Rolland, La Vie de Vivekananda, 118.

${ }^{46}$ Rolland, The Life of Ramakrishna, 15.
} 
According to Rolland, great Indian mystics such as Sri Ramakrishna and Vivekananda - as well as numerous Western mystics, including Plotinus, Pseudo-Dionysius, and Angelus Silesius - realized the truth of metaphysical Unity in which both science and religion culminate: 'At the basis of everything then is force, Divine Force [la Force Divine]. It is in all things and in all men. It is at the centre of the Sphere and at all the points of the circumference' (LV, p. 231). The 'new science of the mind' which Rolland envisioned - rooted in the ancient Indian systems of Rāja Yoga and Jñāna Yoga and revitalized and updated by Vivekananda and Sri Aurobindo - would provide a rigorous scientific method for penetrating to this oceanic 'Force Divine' that unites all of us at the metaphysical core of our being. ${ }^{47}$

\section{Revisiting the Rolland-Freud debate on the oceanic feeling}

With this background in place, we are now in a position to explore the important question: What did Rolland have in mind when he asked Freud in 1927 to provide 'an analysis of spontaneous religious sentiment or, more exactly, of religious feeling'? According to Fisher, ' $[w]$ hat Rolland expected from Freud ... was an empirical psychoanalytic exploration of the various dimensions of the "oceanic" sensation. ${ }^{48}$ Parsons, in his richly informative book The Enigma of the Oceanic Feeling (1999), arrives at a similar conclusion by placing Rolland's 1927 letter to Freud in the broader context of his biographies of Sri Ramakrishna and Vivekananda. ${ }^{49}$ Parsons finds in Rolland's biographies of these Indian saints strong evidence that Rolland's primary motivation in appealing to the oceanic feeling was to enlist Freud in the creation of a 'mystical psychoanalysis' - that is, a non-reductive psychoanalytic approach to mysticism. ${ }^{50}$

Parsons has undoubtedly enriched our understanding of the Rolland-Freud debate on oceanic feeling by taking into account Rolland's biographies of Sri Ramakrishna and Vivekananda. However, Parsons' interpretation of Rolland as the champion of a non-reductive psychoanalysis is based on a selective and inaccurate reading of Rolland's biographies of the Indian saints. Parsons claims that the strongest piece of evidence in favour of his interpretation is Rolland's reference to a 'mystical psychoanalysis' in his biography of Sri Ramakrishna. Tellingly, Parsons cites this striking phrase out of context no fewer than 10 times, but he fails to mention the original French phrase used by Rolland himself. ${ }^{51}$ In fact, 'mystical psychoanalysis' - the phrase so frequently quoted by Parsons - is E.F. Malcolm-Smith's inaccurate English translation of Rolland's original French phrase, 'psychophysiologie mystique,' which would be more accurately translated as 'mystical psychophysiology. ${ }^{52}$

Moreover, the long footnote in which this phrase occurs makes clear that the 'mystical psychophysiology' of which Rolland speaks has absolutely nothing to do with psychoanalysis, mystical or otherwise. In the course of describing Sri Ramakrishna's extraordinary ability to stimulate spiritual experiences in his disciples by a 'little thing' such as 'a word, a look, a touch' (LR, p. 167), Rolland adds a footnote in which he cites the testimony of Swami Shivananda, a disciple of Sri Ramakrishna, who attested to Sri Ramakrishna's ability to transmit to others 'the energy of his own spirituality' (LR, p. 167 fn. 41). Rolland then adds this significant remark:

Let the learned men of Europe, who are preoccupied by the problems of mystical psychophysiology [psychophysiologie mystique] put themselves in touch with these living witnesses [such as Swami Shivananda] while there is yet time. I myself, I repeat, have little curiosity about such phenomena, whose subjective reality is not in doubt, and I believe it my duty to describe them; for they are hedged about by all possible guarantees of good faith and analytical intelligence. I am more interested in the fact of great religious intuition in that

\footnotetext{
${ }^{47}$ Rolland's account of the 'Force Divine' is quite vague, so it is not entirely clear what he means by it. In general terms, however, it is clear that the phrase refers to the single Divine Reality that unites everyone and everything in the universe.

${ }^{48}$ Fisher, 'Sigmund Freud and Romain Rolland', 44. For a similar claim, see Saarinen, 'The Oceanic State', 941.

${ }^{49}$ Parsons, The Enigma of the Oceanic Feeling, 14. See also Saarinen, 'The Oceanic State', 941.

${ }^{50}$ Parsons, Enigma of the Oceanic Feeling, 167.

${ }^{51}$ Parsons refers to 'mystical psychoanalysis' on $58,63,65,134,140,146,162,163,165$, and 167 of Enigma of the Oceanic Feeling.

${ }^{52}$ Romain Rolland, La Vie de Ramakrishna (Paris: Stock, 1929), 239.
} 
which continues to be rather than in that which has been, in that which is or which can be always in all beings rather than in that which is the privilege of a few. (LR, p. $167 \mathrm{fn} .41$ )

What Rolland means by 'mystical psychophysiology' is the unique ability of mystics such as Sri Ramakrishna to stimulate or effect spiritual knowledge in others. In other words, Rolland casts Sri Ramakrishna himself as a mystical psychophysiologist and encourages the learned men of Europe' who are interested in such phenomena to investigate them further. Rolland adds that he himself has 'little curiosity about such phenomena,' not because he is sceptical about them but because his primary concerns lie elsewhere.

One might object, at this point, that while Parsons wrongly claims that Rolland used the phrase 'mystical psychoanalysis,' Parsons may still be correct that Rolland more generally advocated a nonreductive psychoanalytic approach to mysticism. If Rolland had championed such a mystical psychoanalysis, then there would surely be signs of such an approach in his biographies of Sri Ramakrishna and Vivekananda. As we have seen, however, Rolland not only conspicuously refrains from psychoanalysing Sri Ramakrishna and Vivekananda but also expresses his outright hostility toward psychoanalytic approaches to mysticism at various points in his biographies. ${ }^{53}$ In his biography of Vivekananda, Rolland repeatedly calls on psychoanalysts such as Freud and Morel to recognize the limitations and biases of psychoanalysis and to 'complete' their knowledge of the whole mind by taking seriously the mystical experiences of both Western and Eastern saints. Contrary to Parsons, then, I would argue that Rolland does not champion a non-reductive psychoanalytic approach to mysticism anywhere in his biographies.

Parsons claims that 'Rolland ... wanted Freud's help to scientifically establish the benefits of mystical introversion, what he would refer to in his biographies of the Hindu saints as a "universal science-religion" and "mystical psychoanalysis." 54 Here, it becomes clear that Parsons' mistaken claim that Rolland advocated a 'mystical psychoanalysis' has serious consequences for his overall argument about Rolland's intentions in appealing to the oceanic feeling in his 1927 letter to Freud. ${ }^{55}$ While I agree with Parsons that Rolland sought to enlist Freud in the creation of a 'universal science-religion,' Parsons wrongly equates this 'universal science-religion' with 'mystical psychoanalysis. ${ }^{56}$ As I have shown at length in Section I, there is not a single reference to psychoanalysis in Rolland's entire extended account of the 'universal science-religion' in his biography of Vivekananda. In fact, the universal science-religion envisioned by Rolland was based not on psychoanalysis but on the Indian spiritual systems of Rāja Yoga and Jñāna Yoga. Against Parsons, then, I would argue that there is virtually no evidence that Rolland wanted Freud to provide a non-reductive psychoanalytic examination of the oceanic feeling.

In light of Rolland's evident antipathy toward psychoanalytic approaches to mysticism, why did he ask Freud to provide an 'analysis' of the oceanic feeling in his 1927 letter? I would suggest that Rolland appealed to the oceanic feeling as a direct challenge to Freud: the oceanic feeling, precisely because it is a genuine 'contact' with metaphysical Reality attested to by countless people, is not

\footnotetext{
${ }^{53}$ I would like to address a referee's astute objection that my claim here that Rolland was outright hostile even to non-reductive psychoanalytic approaches to mysticism stands in tension with my earlier claim that Rolland's new science of the mind would 'incorporate some of the most valuable insights of psychoanalysis without succumbing to the reductionism prevalent in psychoanalytic approaches to mystical experience.' In Section I, I argued that Rolland saw Rāja Yoga as a therapeutic spiritual method that helps dissolve unconscious psychological complexes more effectively than psychoanalytic methods do. Accordingly, I quoted Rolland as saying: 'The ancient Yogis did not wait for Dr. Freud to teach them that the best cure for the mind is to make it look its deeply hidden monsters straight in the face ...' (LV, p. 192). The Yogic science of the mind Rolland envisioned would incorporate the psychoanalytic insight into the centrality of the unconscious in psychological life but would dissolve unconscious complexes through mystical, rather than psychoanalytic, methods. On my reading, then, there is no scope in Rolland's 'new science of the mind' even for non-reductive psychoanalytic approaches to mysticism.

${ }^{54}$ Parsons, Enigma of the Oceanic Feeling, 38.

${ }^{55}$ I have added this paragraph in order to address a referee's concern that I might be placing 'excessive interpretive weight on a single mistranslated phrase.' Parsons, I argue, makes the non-existent phrase 'mystical psychoanalysis' do a great deal of argumentative heavy-lifting throughout his book.

${ }^{56}$ Parsons makes this mistake elsewhere in the book as well. He refers, for instance, to Rolland's 'promotion of a mystical psychoanalysis characterized as the universal science-religion of the future' (Enigma of the Oceanic Feeling, 163).
} 
vulnerable to Freud's psychoanalytic debunking. In his letter to Freud, Rolland was calling not for any kind of psychoanalytic analysis of mysticism but for a mystically grounded 'science-religion' to replace psychoanalysis altogether. ${ }^{57}$

The somewhat veiled critical thrust of Rolland's appeal to the oceanic feeling is confirmed by the remainder of his letter. Shortly after asking Freud to analyse the oceanic feeling, Rolland remarks that since the oceanic feeling is common to thousands (millions) of men actually existing, with its thousands (millions) of individual nuances, it is possible to subject it to analysis, with an approximate exactitude. ${ }^{58}$ What kind of 'analysis' did Rolland have in mind? I think Rolland answers this question in his biography of Vivekananda, where he calls for a 'new science of the mind' that would subject mystical states to rigorous scientific analysis. Rolland believed that Vivekananda and Sri Aurobindo were the true pioneers in this mystical scientific endeavour. Rolland applauds Vivekananda's attempt to demonstrate that there is 'no essential difference' between 'science and religion' (LV, p. 197). Rolland also approvingly mentions Sri Aurobindo's efforts to incorporate 'religious intuition' into 'the strict limits of science' (LV, p. 205 fn. 104). Hence, when Rolland remarks to Freud that it is possible to subject the oceanic feeling to 'analysis,' I think it is plausible to assume that he had in mind not a psychoanalytic examination but a yogic-cum-scientific analysis of the oceanic feeling along the lines of what Vivekananda and Sri Aurobindo had already begun to develop. This interpretation of Rolland's request to Freud would also be consistent with the many passages in his biography of Vivekananda where Rolland encourages psychoanalysts to learn from ancient Indian yogic science instead of engaging in reductive analyses of mystical phenomena.

In the next paragraph of the letter, Rolland predicts that Freud would classify the oceanic feeling 'under the Zwangsneurosen. ${ }^{59}$ (Rolland proved to be right, since Freud would go on to interpret the oceanic feeling in Das Unbehagen in der Kultur as a regression to a pre-Oedipal state.) In a canny move, Rolland preemptively rejects this psychoanalytic debunking of the oceanic feeling, insisting that both Western and non-Western mystics have experienced the 'rich and beneficent power' of the oceanic feeling. Citing Sri Ramakrishna and Vivekananda as examples, Rolland adds that the oceanic feeling is perfectly compatible with the utmost 'aptitude for thought and action. ${ }^{60}$

In the beginning of 1930, Rolland sent Freud his biographies of Sri Ramakrishna and Vivekananda in the hope that Freud would step outside the narrow confines of psychoanalysis and try to learn from the mystical insights of Indian Yoga and yogis. Upon receiving the biographies, however, Freud confesses in a letter to Rolland dated 19 January 1930 that 'it isn't easy to pass beyond the limits of one's nature. ${ }^{61}$ After responding briefly to Rolland's criticisms of psychoanalysis in the Appendix to Vie de Vivekananda, Freud makes this significant remark:

We seem to diverge rather far in the role we assign to intuition. Your mystics rely on it to teach them how to solve the riddle of the universe; we believe that it cannot reveal to us anything but primitive, instinctual impulses and attitudes - highly valuable for an embryology of the soul when correctly interpreted, but worthless for orientation in the alien, external world. ${ }^{62}$

\footnotetext{
${ }^{57} \mathrm{~A}$ referee objects that 'Parsons seems well aware of the complexity and critical nature of Rolland's intentions.' The referee mentions, as an example, Parsons' claim that Rolland's call for a scientific and religious psychology 'could not be seen by Freud as anything less than a competitor to a psychoanalysis envisioned as the "secular cure of souls"' (Enigma of the Oceanic Feeling, 72). While I agree with the referee that Parsons recognizes the critical thrust of Rolland's appeal to the oceanic feeling, I think Parsons' understanding of Rolland's critical intentions is insufficiently radical. For Parsons, Rolland's mystical criticisms of Freudian psychoanalysis were meant to encourage Freud to adopt a less reductive psychoanalytic approach to mysticism (along the lines of the 'adaptive-transformative' psychoanalytic approaches discussed at length by Parsons). On my reading, however, Rolland's mystical criticisms of psychoanalysis were much more radical than Parsons allows, since they suggest that the psychoanalytic paradigm as such yields a reductive understanding of mysticism. Hence, while Parsons claims that Rolland did not exhibit 'active hostility toward psychoanalytic modes of investigation' (Enigma of the Oceanic Feeling, 156), I have been arguing that Rolland was actively hostile towards psychoanalytic approaches to mysticism in general.

${ }^{58}$ Parsons, Enigma of the Oceanic Feeling, 173.

${ }^{59}$ lbid.

${ }^{60}$ Ibid.

${ }^{61}$ Ibid., 176.

${ }^{62}$ lbid., 177.
} 
It is clear from this remark that Freud rejects outright Rolland's view that mystical intuition is a scientific instrument that can help us gain deeper insight into reality. Freud simply reiterates his position in Das Unbehagen in der Kultur that the oceanic feeling reveals nothing but 'primitive, instinctual impulses.'

Interestingly, after Rolland received and read Freud's Unbehagen in der Kultur, Rolland wrote a letter to Freud dated 3 May 1931 in which he expresses disappointment with Freud's psychoanalytic interpretation of the oceanic feeling as a regression to a pre-Oedipal state. Rolland implicitly challenges Freud's psychoanalytic denigration of the oceanic feeling by insisting that his oceanic feeling is 'a psychological fact, a vital trait of my character' and that it is 'absolutely disinterested. ${ }^{63}$ Moreover, Rolland reiterates that he has received letters from people 'from all corners of the earth' who have also experienced this oceanic feeling. ${ }^{64}$ Rolland thereby implicitly responds to Freud's claim in Das Unbehagen in der Kultur that the true source of religion is not the oceanic feeling but the childish feeling of helplessness and need for the father's protection. Rolland clearly feels that Freud has trivialized the oceanic feeling, which is why Rolland issues the warning: 'It would be dangerous for the philosopher and man of action to ignore' the many occurrences of the oceanic feeling throughout the world. ${ }^{65}$

Rolland had sincerely hoped - perhaps naively - that his mystical account of the oceanic feeling and his biographies of Sri Ramakrishna and Vivekananda would lead Freud to accept the scientific validity of mysticism and to move beyond a narrowly psychoanalytic understanding of the workings of the psyche. Instead, Freud dug his heels in even further, reiterating his psychoanalytic dismissal of mystical experience and insisting that science and mysticism are worlds apart.

\section{Rolland's anticipation of later mystical critiques of psychoanalysis}

Parsons, as we have seen, argues that Rolland's primary aim in appealing to the oceanic feeling was to encourage Freud to adopt a sympathetic and non-reductive psychoanalytic approach to mystical experience. According to Parsons, Freud adopted a "classic" reductionist' approach to mysticism, since he dismissed the oceanic feeling as a regression to an infantile state. ${ }^{66}$ Rolland, by contrast, anticipated what Parsons calls the 'adaptive' and 'transformative' psychoanalytic approaches to mysticism which developed after Freud's time. ${ }^{67}$ While the adaptive approach frames mysticism as a 'healing enterprise,' the transformative approach goes even further by allowing 'meta-psychological space for the deeper, transcendent claims of the mystics. ${ }^{68}$ In Parsons' view, Rolland adopted an 'adaptive-transformational' approach to mysticism, which paved the way for later non-reductive psychoanalytic approaches to mysticism. ${ }^{69}$

I have argued, by contrast, that Rolland's biographies of Sri Ramakrishna and Vivekananda reveal a scepticism toward psychoanalysis that is much more radical and far-reaching than Parsons assumes. I would suggest, then, that Rolland's true heirs are not post-Freudian psychoanalysts who have explored non-reductive approaches to mysticism but twentieth-century mystics in both the East and the West who have highlighted the fundamental defects and limitations of psychoanalysis from a mystical perspective. ${ }^{70}$ To begin to make my case, I will briefly demonstrate how

\footnotetext{
${ }^{63}$ Ibid., 178.

${ }^{64}$ Ibid.

${ }^{65}$ Ibid.

${ }^{66}$ Parsons, "'Let Him Rejoice in the Roseate Light!"', 81.

${ }^{67}$ Ibid., 92-3, and Parsons, Enigma of the Oceanic Feeling, 109.

${ }^{68}$ Parsons, "'Let Him Rejoice in the Roseate Light!"', 93.

${ }^{69}$ lbid.

${ }^{70} \mathrm{~A}$ referee asks whether it might be more accurate to claim that 'Rolland's non-psychoanalytic mystical legacy complements rather than supplants his other, adaptive-transformative psychoanalytic legacy.' To clarify my position, I would agree with Parsons that Rolland's criticisms of Freudian psychoanalytic approaches to mysticism did pave the way for later adaptive-transformative critiques of Freudian reductionism. However, contrary to Parsons, I do not think there is any convincing evidence that Rolland actually advocated adaptive-transformative psychoanalytic approaches to mysticism. Therefore, I stand by my claim that Rolland's true heirs are not adaptive-transformative psychoanalysts but mystics who have criticized psychoanalytic methods.
} 
Rolland's criticisms of psychoanalysis and his call for a new Yogic 'science of the mind' anticipated the sophisticated critiques of psychoanalysis provided by mystics as diverse as Sri Aurobindo (18721950), Swami Akhilananda (d. 1962), and Ken Wilber (b. 1949).

Throughout his biography of Vivekananda, Rolland refers approvingly to, and cites numerous passages from, a variety of Sri Aurobindo's works, including Essays on the Gita (1916), The Synthesis of Yoga (1921), and The Life Divine (1919). As we have already seen, Rolland especially applauded Sri Aurobindo's efforts to integrate spiritual intuition into science and thereby to bridge the gap between Western rationalism and Indian spirituality. While the works of Sri Aurobindo with which Rolland was familiar do not contain any remarks on Freud or psychoanalysis, Sri Aurobindo wrote a number of letters to disciples in the 1930s - of which Rolland could not have been aware - in which he made numerous critical remarks about psychoanalysis. Unfortunately, I have not been able to determine whether Sri Aurobindo read Rolland's Life of Vivekananda. If he had, he may very well have been influenced by Rolland's criticisms of psychoanalysis, especially in his Appendix on Morel. ${ }^{71}$ Setting aside this speculative issue of direct influence, I will briefly point out four striking affinities between Sri Aurobindo's and Rolland's respective critiques of psychoanalysis.

First, Sri Aurobindo claims that Freud's psychoanalytic theory stems from pathology. In a 1936 letter to Sri Aurobindo, one of Sri Aurobindo's disciples made the following scathing remark about Freud:

The extreme of ridiculousness is reached when Freud analyses Leonardo da Vinci to show how he was pathological, how he failed disastrously in his adaptation to life, how his artistic imagination was an aberration and a maladaptation. All poets, all imaginative people, all genuises, all religious people were to Freud the result of aberration and maladaptation. ${ }^{72}$

In a response to this letter, Sri Aurobindo seconds the sentiment of his disciple: 'Well, his [Freud's] own theory is very clearly that, the result of aberration and maladaptation. ${ }^{, 73}$ Rolland, as we have seen, claims that the psychoanalytic 'depreciation' of introversion of all sorts 'is in danger of becoming a pathological aberration.' In a striking echo of Rolland, Sri Aurobindo turns the tables on Freud - or, perhaps more aptly, puts Freud on the couch - by claiming that Freud's own tendency to pathologize artistic and religious geniuses stems from a pathological 'aberration and maladaptation. ${ }^{74}$

Second, Sri Aurobindo claims that psychoanalytic theories are false generalizations based on an incomplete understanding of the workings of the unconscious:

The psychoanalysis of Freud is the last thing that one should associate with yoga. It takes up a certain part, the darkest, the most perilous, the unhealthiest part of the nature, the lower vital subconscious layer, isolates some of its most morbid phenomena and attributes to it and them an action out of all proportion to its true role in the nature. Modern psychology is an infant science, at once rash, fumbling and crude. As in all infant sciences, the universal habit of the human mind - to take a partial or local truth, generalise it unduly and try to explain a whole field of Nature in its narrow terms - runs riot here. Moreover, the exaggeration of the importance of suppressed sexual complexes is a dangerous falsehood and it can have a nasty influence and tend to make the mind and vital more and not less fundamentally impure than before. ${ }^{75}$

According to Sri Aurobindo, Freudian psychoanalysis mistakes the 'darkest' and 'unhealthiest' part of the unconscious for the unconscious as a whole and, on that basis, proceeds to make unjustified generalizations about how unconscious drives influence conscious behaviour and activity. Moreover,

\footnotetext{
${ }^{71}$ However, it should be noted that Sri Aurobindo sometimes made critical remarks about Rolland in his letters to disciples. For instance, he remarks that Rolland mistakenly 'takes his emotional intellectuality for spirituality.' See Sri Aurobindo, Letters on Yoga I (The Complete Works of Sri Aurobindo, vol. 28 [Pondicherry: Sri Aurobindo Ashram Press, 2012]), 324. Nonetheless, Sri Aurobindo's scepticism about Rolland's credentials as a mystic does not rule out the possibility that Sri Aurobindo was influenced by Rolland's criticisms of psychoanalysis.

${ }^{72}$ Sri Aurobindo, Letters on Poetry and Art (The Complete Works of Sri Aurobindo, vol. 27 [Pondicherry: Sri Aurobindo Ashram Press, 2004]), 528.

${ }^{73}$ Sri Aurobindo, Letters on Poetry and Art, 528 (letter dated 1 June 1936).

${ }^{74}$ Ibid.

${ }^{75}$ Sri Aurobindo, Bases of Yoga (Pondicherry: Sri Aurobindo Ashram, 1981 [1936]), 70-1.
} 
just as Rolland found the psychoanalytic 'obsession ... with sexual things' to be 'false and revolting," ${ }^{, 76}$ Sri Aurobindo claims that Freud exaggerates the 'importance of suppressed sexual complexes,' thereby hindering the patient's recovery. ${ }^{77}$

Sri Aurobindo points out that Freud's view of the unconscious is incomplete because it focuses exclusively on the 'lower vital subconscious,' which is 'no more than a restricted and very inferior portion of the subliminal whole. ${ }^{78}$ According to Sri Aurobindo, the 'subliminal self is in fact much vaster and its dynamics much richer and more complex than Freud assumes. Sri Aurobindo claims that the subliminal self also 'opens to higher superconscient ... ranges,' and he insists that true psychic transformation and purification can only be achieved by ascending to the superconscious plane: 'If one wishes to purify and transform the nature, it is the power of these higher ranges to which one must open and raise to them and change by them both the subliminal and the surface being. ${ }^{, 79}$ While Sri Aurobindo and Rolland hold similar views on the limitations of the Freudian conception of the unconscious, they differ somewhat in their understanding of the ontological basis of mystical experience. Rolland, as we have seen, locates the oceanic feeling at the most archaic level of the unconscious. Sri Aurobindo, by contrast, claims that genuine spiritual experience takes place at the level of the 'superconscient,' from which one can begin the work of transforming both the conscious and the subliminal planes. ${ }^{80}$

Third, Sri Aurobindo argues that psychoanalytic explanations of spiritual experience are both crude and woefully inadequate because they are based on the false presupposition that the unconscious is 'the true foundation of things':

I find it difficult to take these psycho-analysts at all seriously when they try to scrutinise spiritual experience by the flicker of their torch-lights ... . They look from down up and explain the higher lights by the lower obscurities; but the foundation of these things is above and not below, upari budhna eșam. The superconscient, not the subconscient, is the true foundation of things. The significance of the lotus is not to be found by analysing the secrets of the mud from which it grows here; its secret is to be found in the heavenly archetype of the lotus that blooms for ever in the Light above. ${ }^{81}$

According to Sri Aurobindo, the fundamental mistake of psychoanalysis is the assumption that one can 'explain the higher lights by the lower obscurities.' Spiritual experience, like the lotus in Sri Aurobindo's metaphor, cannot be explained by analysing the 'mud' of the unconscious but by rising to a superconscient divine plane. Implicit in Sri Aurobindo's remark is a critique of the dogmatic positivism underlying psychoanalysis: since psychoanalysts dismiss the very possibility of a superconscient plane of experience, they inevitably explain away mystical experience in terms of unconscious strivings.

Fourth, Sri Aurobindo claims that his own 'Integral Yoga' - which harmonizes and modernizes the ancient Indian systems of Rāja Yoga, Bhakti Yoga, Jñāna Yoga, and Karma Yoga - provides a far more adequate psychological framework both for understanding the workings of the mind and for achieving spiritual fulfilment. Referring to psychoanalysts, Sri Aurobindo remarks:

The self-chosen field of these psychologists is besides poor, dark and limited; you must know the whole before you can know the part and the highest before you can truly understand the lowest. That is the promise of the greater psychology awaiting its hour before which these poor gropings will disappear and come to nothing. ${ }^{82}$

\footnotetext{
${ }^{76}$ Cited in Werman,' Sigmund Freud and Romain Rolland', 230.

${ }^{77}$ Sri Aurobindo claims elsewhere that the 'forced connection with sex' in psychoanalytic theory is 'quite groundless.' See Sri Aurobindo, Letters on Himself and the Ashram (The Complete Works of Sri Aurobindo, vol. 35 [Pondicherry: Sri Aurobindo Ashram Press, 2011]), 9.

${ }^{78}$ Sri Aurobindo, Bases of Yoga, 71.

${ }^{79}$ lbid.

${ }^{80}$ Sri Aurobindo provides a detailed account of the nature of the superconscient in The Life Divine (The Complete Works of Sri Aurobindo, vols. 21-22 [Pondicherry: Sri Aurobindo Ashram Press, 2005) and The Synthesis of Yoga (The Complete Works of Sri Aurobindo, vols. 23-24 [Pondicherry: Sri Aurobindo Ashram Press, 1999]).

${ }^{81}$ Sri Aurobindo, Bases of Yoga, 73.

${ }^{82} \mathrm{lbid}$.
} 
Rolland, in his Appendix on Morel, encouraged psychoanalysts to 'complete' their 'knowledge of the whole activity of the mind' by learning from the testimony of both Eastern and Western mystics. Several pages later, Rolland singled out 'Aurobindo Ghose' as 'one of the greatest thinkers of modern India' who is trying to develop the very Yogic psychology that Rolland himself had in mind (LV, p. 286). Sri Aurobindo himself was quite consciously developing his Integral Yoga as a 'greater psychology' infinitely superior to the 'poor gropings' of psychoanalysis. For both Rolland and Sri Aurobindo, the ancient Indian systems of Yoga were a far more promising basis for this 'greater psychology' than psychoanalysis.

In his book Hindu Psychology: Its Meaning for the West (1948), Swami Akhilananda, a monk of the Ramakrishna Order, also makes numerous criticisms of psychoanalysis that are akin to Rolland's. Indeed, early on in his book, Akhilananda refers approvingly to Rolland's Life of Ramakrishna, so he might also have been aware of - and perhaps even influenced by - Rolland's criticisms of psychoanalysis in the Life of Vivekananda. ${ }^{83}$ Here, however, I will set aside the question of whether Akhilananda was directly influenced by Rolland's views and restrict myself to pointing out some parallels between Akhilananda's and Rolland's critical views on psychoanalysis. As I pointed out in Section I, Rolland claims that psychoanalysts have 'erroneously extended' the theory of regression, which is 'undoubtedly a true one' in regard to cases of pathology, to 'the whole realm of the mind, whether abnormal or normal.' Similarly, Akhilananda observes, 'It seems that Freud and other psychoanalysts make unnecessary and uncalled-for generalizations from the study of pathological cases. ${ }^{, 84}$ Akhilananda claims that two of Freud's theories in particular are based on such unjustified generalizations: first, Freud's thesis that the 'sex urge ... is the most predominant instinct,' and second, Freud's theory of the 'death instinct. ${ }^{, 85}$ According to Akhilananda, 'Hindu psychologists do not agree with the view that man has a basic destructive tendency. Suicide, war, and all other such destructive tendencies are not expressions of the normal mind. ${ }^{86}$

Moreover, just as Rolland claimed that Western psychologists have largely ignored or misunderstood mystic introversion because of their tendency toward 'extroversion,' Akhilananda remarks with regard to American psychology: 'It should be noted here that great emphasis is given to "action" in most of the schools of psychology in America ... .Consequently, the subjective element of mind is ignored. In fact, meditation and inner understanding are generally neglected. ${ }^{87}$ Like Sri Aurobindo, Akhilananda attacks the positivist attitude among many psychoanalysts which leads them to 'make superficial remarks about the religious tendencies of man in terms of sex. ${ }^{88}$ Akhilananda traces the inadequacy of psychoanalytic explanations of spiritual experience to a positivist scepticism toward 'supernormal' possibilities of the mind: 'Actually, the supernormal minds function in a manner quite different from normal and abnormal cases. This is the reason that the unfortunate generalizations of many of the psychotherapeutists regarding spiritual experiences are extremely inaccurate and unscientific. ${ }^{89}$

Akhilananda also echoes Rolland in claiming that psychologists such as Freud, Adler, and Jung focus unduly on the unconscious at the expense of other equally essential aspects of the mind and human personality. Hindu psychologists, by contrast, 'are primarily interested in the study of the total mind, as they feel that the different functions - including consciousness, superconsciousness, cognition, volition, and conation - cannot be really separated. ${ }^{90}$ By 'Hindu psychology' Akhilananda means primarily Patañjali's Yoga system, especially as developed and elaborated by Vivekananda.

\footnotetext{
${ }^{83}$ Akhilananda remarks, 'The writings of Romain Rolland, Professor Hocking, and others prove that the dynamic ideas of Sri Ramakrishna have a direct influence on the world.' See Swami Akhilananda, Hindu Psychology: Its Meaning for the West (London: Routledge \& Kegan Paul, 1948), 7.

${ }^{84}$ Ibid., 7 .

${ }^{85}$ Ibid.

${ }^{86} \mathrm{Ibid}$.

${ }^{87}$ Ibid., 10.

${ }^{88}$ lbid., 18.

${ }^{89}$ lbid.

${ }^{90}$ Ibid., 16.
} 
According to Akhilananda, the aim of Hindu psychology is 'total integration of the mind, ${ }^{91}$ which is achieved by the combined practices of self-analysis, concentration, and meditation:

According to the Hindu view, not only must one analyze one's own self but at the same time one must reconstruct his life .... We observe that many disintegrated minds are synthesized by the combined methods of selfanalysis and concentration. A mere discovery of mental conflict, by either the Freudian method of psychoanalysis, [Carl] Rogers' insight, or self-analysis, does not integrate the mind. ${ }^{92}$

Like Rolland, Akhilananda insists that mental conflicts can only be fully dissolved through Yogic practice, which integrates the mind as a whole. Akhilananda quite presciently emphasizes the psychological benefits of concentration: 'Our experience proves it is the practice of concentration that brings out hidden mental forces which reconstruct and integrate the whole mind. ${ }^{93}$ In agreement with Sri Aurobindo, Akhilananda argues that the psychoanalytic method of treatment is, at best, partially or transiently curative and, at worst, dangerous and potentially counter-productive.

Rolland also anticipated some of the insights and arguments of Ken Wilber, a major contemporary theorist and champion of transpersonal psychology. In light of space limitations, I will only mention one especially striking resonance between Rolland's and Wilber's respective critiques of psychoanalysis. Rolland, drawing on the work of the Bergsonian Eduouard Le Roy, argues that the psychoanalyst mistakes the post-discursive state of the mystic with the pre-discursive state of the infant (LV, p. 282 fn. 10). Strikingly, Rolland and Le Roy anticipated by over half a century Wilber's now well-known notion of the 'pre/trans fallacy.' As Wilber observes, 'The essence of the pre/ trans fallacy is itself fairly simple: since both prerational and transrational states are, in their own ways, nonrational, they appear similar or even identical to the untotored eye. ${ }^{.94}$

Interestingly, Wilber specifically targets Freud's psychoanalytic explanation of the oceanic feeling in terms of regression as a paradigmatic case of the pre/trans fallacy:

Genuine mystical or contemplative experiences, for example, are seen as a regression or throwback to infantile states of narcissism, oceanic adualism, indissociation, and even primitive autism. This is, for example, precisely the route taken by Freud in The Future of an Illusion. ${ }^{95}$

Moreover, Wilber astutely traces this reductive tendency among psychoanalysts to their dogmatic assumption that 'rationality is the great and final omega point of individual and collective development, the high-water mark of all evolution. ${ }^{96}$ As Wilber archly observes, such a dogmatic rationalism necessarily entails the positivistic dismissal of the very possibility of transrational states:

Since no higher context is thought to be real, or to actually exist, then whenever any genuinely transrational occasion occurs, it is immediately explained as a regression to prerational structures .... The superconscious is reduced to the subconscious, the transpersonal is collapsed to the prepersonal, the emergence of the higher is reinterpreted as an irruption from the lower. All breathe a sigh of relief, and the rational worldspace is not fundamentally shaken ... ${ }^{97}$ emphasis in the original

Rolland's Appendix on Morel, I would suggest, contains the seeds of Wilber's provocative metacritique of the positivistic rationalism lurking at the basis of psychoanalysis. In the Appendix, after applauding Sri Aurobindo's attempt to 'reintegrate generative intuition' into science, Rolland launches into a spirited attack on 'exclusive rationalists' such as Freud who dogmatically reject the 'great effort' of mystics like Sri Aurobindo (LV, p. 286). The positivistic rationalism of

\footnotetext{
${ }^{91}$ Ibid., 17.

${ }^{92}$ Ibid., $64-5$.

${ }^{93}$ Ibid., 65.

${ }^{94}$ Ken Wilber, The Essential Ken Wilber: An Introductory Reader (Boston: Shambhala, 1998), 88.

${ }^{95}$ Wilber, The Essential Ken Wilber, 88. 'Indissociation' is the term used by the Swiss psychologist Jean Piaget to refer to the failure of young children to differentiate themselves from their environments. See Andrew Colman, Oxford Dictionary of Psychology (Oxford: Oxford University Press, 2003), 357. 'Primitive autism' is a type of autism in which the subject displays 'primitive means of relating to the environment, such as smelling and mouthing.' See Bryna Siegel et al., 'Empirically Derived Subclassification of the Autistic Syndrome', Journal of Autism and Developmental Disorders 16, no. 3 (1986): 286.

${ }^{96}$ Wilber, The Essential Ken Wilber, 88.

${ }^{97}$ lbid., 88-9.
} 
psychoanalysts, according to Rolland, is based on nothing more than 'prejudices' that have become 'second nature.' Wilber echoes Rolland in his sarcastic nod to 'the rational worldspace' in which psychoanalysts have snugly - perhaps irrationally? - ensconced themselves.

In the past few decades, many Western psychologists and psychiatrists have begun to incorporate Eastern meditative techniques into their treatment of patients suffering from various kinds of psychological problems and unhealthy addictions. ${ }^{98}$ Seen from this perspective, Rolland's criticisms of psychoanalysis and his call for a new Yogic science of the mind have proven to be both timely and enduring.

\section{Disclosure statement}

No potential conflict of interest was reported by the author.

\footnotetext{
${ }^{98}$ See, for instance, Ruth A. Baer, 'Mindfulness Training as a Clinical Intervention: A Conceptual and Empirical Review', Clinical Psychology: Science and Practice 10, no. 2 (2003): 125-43; John H. Engler, 'Therapeutic Aims in Psychotherapy and Meditation', in Transformations of Consciousness, ed. Ken Wilber et al. (London: Shambhala, 1986), 17-51; Daniel Goleman, 'Meditation and Consciousness: An Asian Approach to Mental Health', American Journal of Psychotherapy 30, no. 1 (1975): 41-54; Eric L. Garland, Brett Froeliger, and Matthew O. Howard, 'Mindfulness Training Targets Neurocognitive Mechanisms of Addiction at the AttentionAppraisal-Emotion Interface', Frontiers in Psychiatry 4 (Jan. 2014): 1-16; Katie Witkiewitz, Alan G. Marlatt, and Denise Walker, 'Mindfulness-Based Relapse Prevention for Alcohol and Substance Use Disorders', Journal of Cognitive Psychotherapy 19, no. 3 (2005): 211-28.
} 